\title{
The genus Blumenavia (Clathraceae, Phallales)
}

\author{
Trierveiler-Pereira $\mathbf{L}^{1^{*}}$, Alves $\mathbf{C R}^{2^{*}}$ and Silveira $\mathbf{R M B}^{3}$
}

Programa de Pós-Graduação em Botânica, Universidade Federal do Rio Grande do Sul, Porto Alegre, Brazil. ${ }^{1}$ lt_pereira@yahoo.com.br, ${ }^{2}$ camila_biograndensis@hotmail.com, ${ }^{3}$ rosa.silveira@ufrgs.br

*both authors contributed equally to this study and should be considered co-first authors.

Trierveiler-Pereira L, Alves CR, Silveira RMB 2014 - The genus Blumenavia (Clathraceae, Phallales). Mycosphere 5(3), 496-501, Doi 10.5943/mycosphere/5/3/12

\begin{abstract}
In this manuscript we present descriptions, comments, illustrations, color photographs and a key to identify the two known species of Blumenavia: $B$. rhacodes and B. angolensis. Both species occur in Southern Brazil and the presented data are based on recently collected and herbarium specimens. Blumenavia angolensis is reported for the first time from the States of Santa Catarina and Rio Grande do Sul (Southern Brazil).
\end{abstract}

Key words - Gasteromycetes - Laternea - lattice stinkhorns - Neotropical fungi - Phallaceae.

\section{Introduction}

Blumenavia Möller is a curious clathroid genus described from Southern Brazil at the end of the 19th century (Möller 1895). Its etymology is dedicated to the city Blumenau, where the German naturalist Alfred Möller lived and studied phalloid fungi from 1890 to 1893 (Stafleu \& Cowan 1983). This genus is differentiated from other clathroids due to the unique morphology of the receptacle, since the gleba is not spread in the inner surface of the columns (or receptacle) or concentrated in droplets (glebifers). Instead, the gleba is spread on lateral projections and lacerations from the columns, also called 'wings' and 'teeth' by some authors.

Lloyd (1909) reduced Blumenavia to a synonym of Laternea Turpin, a position followed by Rick (1929, 1961); however, most authors continued treating the genus independently (Fischer 1933, Dennis 1953, Dring 1980, López et al. 1981, Miller \& Miller 1988, Domínguez de Toledo 1995). Recent molecular studies have shown that Blumenavia is phylogenetically closely related to Laternea (Degreef et al. 2013, Trierveiler-Pereira et al. 2014), but more sequences of both genera must be included in further analysis to clarify their distinction.

To date, four species have been described for the genus: $B$. rhacodes Möller (type species), $B$. angolensis (Welw. \& Curr.) Dring (from Africa, but also known from South America), $B$. usambarensis Henn. (from Africa) and B. toribiotalpaensis Vargas-Rodr. (from Mexico). Calonge et al. (2007) reduced the latter to a synonym of $B$. rhacodes, and B. usambarensis is synonym with B. angolensis (Dring 1980).

In Southern Brazil, the two currently accepted Blumenavia species are not difficult to find in the field, but since their receptacles are so fragile and ephemeral, especially in B. angolensis, they have been considered rare species. The aim of this study is to present full descriptions, comments and illustrations of both species and clearly mark the morphological differences. 


\section{Materials \& Methods}

Field expeditions have been carried in the three States of Southern Brazil (Paraná, Santa Catarina and Rio Grande do Sul) and also specimens from herbaria ICN, FLOR, PACA, MBM, and BPI were consulted (Thiers 2011). Whenever possible, basidiomata were photographed in the field, and later were slowly dried in laboratory using a food dehydrator (at least for 24 hours).

Specimens were examined according to traditional techniques on gasteromycetes taxonomy (Miller \& Miller 1988). Colors were coded according to Kornerup \& Wanscher (1978).

\section{Results}

Blumenavia angolensis (Welw. \& Curr.) Dring, Kew Bull. 35(1): 53 (1980).

Figs 1, 3B

$\equiv$ Laternea angolensis Welw. \& Curr., Trans. Linn. Soc. London 26: 286 (1870).

= Blumenavia usambarensis Henn., Bot. Jb. 33: 37 (1902).

Unexpanded basidiomata ('eggs') not observed. Basidiomata solitary, 4-6 cm high. Volva $0.8-1 \mathrm{~cm}$ high $\times 1-1.5 \mathrm{~cm}$ in diam., pale grey (1B1) to brownish grey $(5 \mathrm{C} 2)$, with debris adhered to the surface and a thin mycelial strand attached at the base. Receptacle pure white when fresh (4A3) and light brown (5D5) when dried, fragile, spongy, with pores on the outer surface (pores internally occluded), formed by four columns, united at the apex and free below; columns $0.3-0.8 \mathrm{~cm}$ in diam. in the largest dimension; subtriangular to subglobose in tranversal section, multi-tubular, composed of 4-5 tubes, not interconnected. Angle between the inner face and outer face of the columns is marked by a line of delicate teeth, which are covered with glebal mass. Gleba gelatinous, olive brown (4F4), fetid. Basidiospores cylindrical, usually attenuate at one side, $4 \times 2$ $\mu \mathrm{m}$, smooth, faintly greenish tinted. Volva's exoperidium formed by pseudoparenchymatous hyphae, 25-45 $\times 15-35 \mu \mathrm{m}$ in diam., yellowish to hyaline, with large, greenish crystals rosette arrangements inside. Receptacle formed by pseudoparenchymatous hyphae, hyaline, 30-40 × 20$35 \mu \mathrm{m}$ in diam., globose, subglobose to elongate; lateral projections ('teeth') also pseudoparenchymatous.

Habitat - growing on wood and other plant debris, on forest litterfall.

Known distribution - Tropical: Africa (Angola - Welwitsch \& Currey 1870; São Tomé Degreef et al. 2013) and South America (Brazil - Meijer 2006).

Material examined - Brazil, State of Paraná, Antonina, Reserva Natural do Rio Cachoeira, 17 Aug 2005, A.A.R. de Meijer 4339 (MBM); Santa Catarina, Florianópolis, Unidade de Conservação Desterro, 9 Nov 2013, A.C. Magnago 816 (FLOR 51619); State of Rio Grande do Sul, São Francisco de Paula, FLONA de São Francisco de Paula, 8 Feb 2014, C.R. Alves 143 (ICN 177268); ibid., 13 Apr 2014, A.C. Magnago 1049 (ICN 177269).

Blumenavia rhacodes Möller, Bot. Mitt. Trop. $7: 57$ (1895).

Figs 2, 3A

= Blumenavia toribiotalpaensis Vergas-Rodr., in Vargas-Rodriguez \& Vázquez-García, Mycotaxon 94: 8 (2006) [2005]

Unexpanded basidiomata ('eggs') globose to depressed globose, $1.5-3.5 \mathrm{~cm}$ diam., dirty white, grayish (2B1) to black. Basidiomata solitary or in small groups, 9-13 cm high. Volva 2.5$3.5 \mathrm{~cm}$ high, with the same morphological features as the immature stages. Receptacle formed by three to five robust columns that are free at the base and united above, columns $1-2 \mathrm{~cm}$ in diam. in the largest dimension, pastel yellow (1A4) to pale yellow (1A3), with a spongy texture and some larger pores on the outer surface (but pores are internally occluded); trapezoid in transversal section, multi-tubular, composed of 8-10 tubes, not interconnected, with the widest tube on the adaxial face. Gleba mucilaginous, olive (2F5), fetid, spread on lateral projection or lacerations of the receptacle's columns. Basidiospores cylindrical, usually attenuate at one side, 3.5-4.5 × 1-1.5 $\mu \mathrm{m}$, smooth, faintly greenish tinted. Volva's exoperidium formed by pseudoparenchymatous hyphae, up to $70 \mu \mathrm{m}$ in diam., yellowish to hyaline, many of them with large crystals rosette arrangements inside; endoperidium formed by hyaline hyphae, simple septate, thin-walled. 
Receptacle formed by pseudoparenchymatous hyphae, up to $40 \mu \mathrm{m}$ in diam., hyaline; lateral projections also pseudoparenchymatous.

Habitat - on rotten wood inside forest and shady places.

Known distribution - Neotropical: Southern Brazil (Möller 1895, Rick 1929, TrierveilerPereira et al. 2014), Northeastern Brazil (Rodrigues \& Baseia 2013, as B. angolensis), Argentina (Domínguez de Toledo 1995), and Mexico (López et al. 1981, Vargas-Rodríguez \& VázquezGarcía 2005, Calonge et al. 2007).

Material examined - Brazil, State of Rio Grande do Sul, São Leopoldo, 1906, J. Rick (PACA-FR 12550); ibid., 1907, J. Rick (PACA-FR 12552); ibid., J. Rick (BPI 703249); Porto Alegre, Morro Santana, 17 May 2011, L. Trierveiler-Pereira 230 (ICN 176968); ibid., 31 May 2011, L. Trierveiler-Pereira 247 (ICN 176969); ibid., Campus da Universidade Federal do Rio Grande do Sul, 01 Apr 2014, E.P. Fazolino 164 (ICN 177266); ibid., 02 Apr 2014, E.P. Fazolino 165 (ICN 177267); Mexico, Jalisco, Talpa de Allende, 10 Sep 2002, Vargas-Rodriguez et al. 240 (BPI 870955, type of Blumenavia toribiotalpaensis).
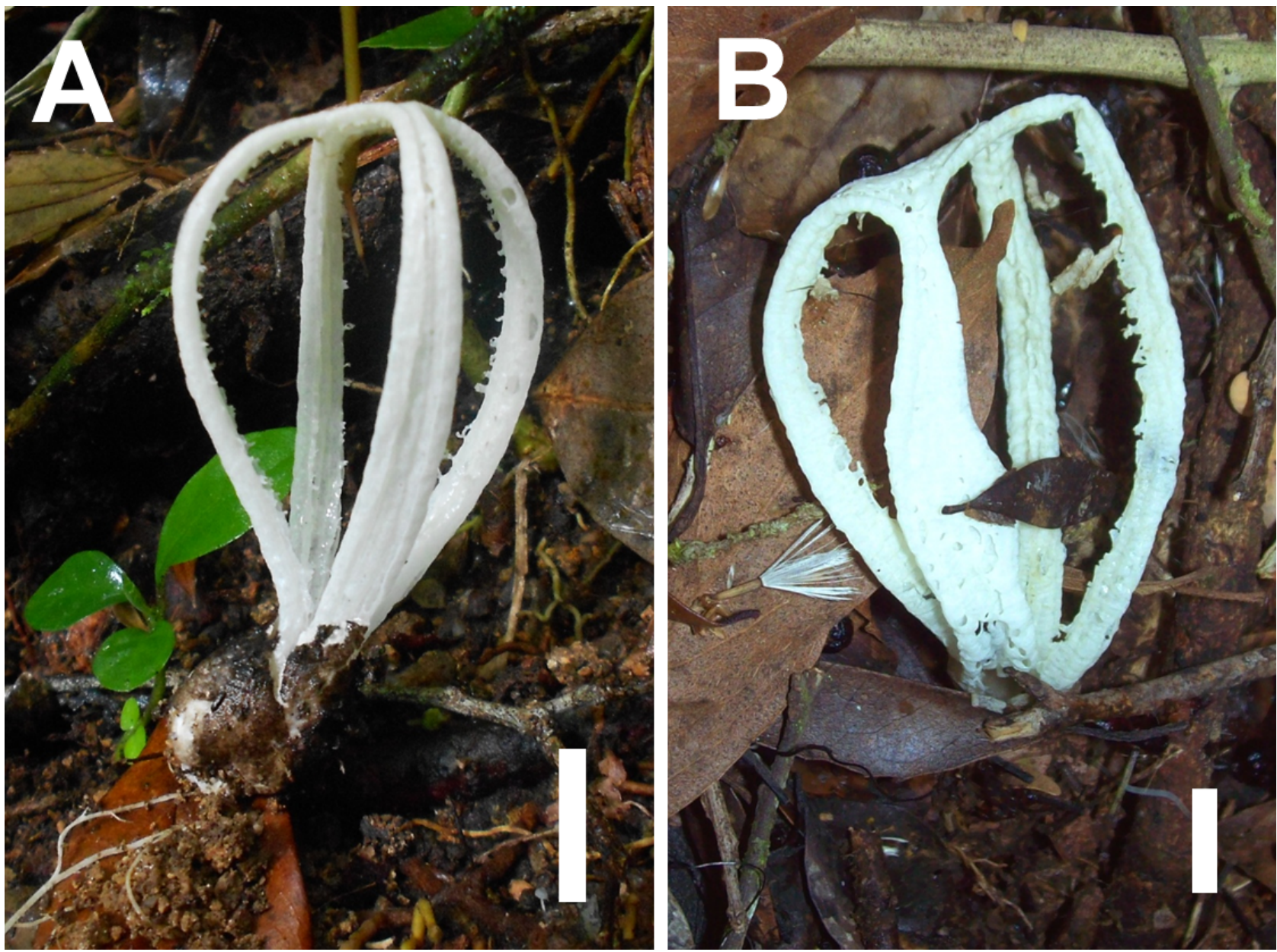

Figure 1 - Blumenavia angolensis in situ. A Specimen FLOR 51619. B Specimen ICN 177268. Bars $=1 \mathrm{~cm}$. Photograph A by A.C. Magnago.

\section{Discussion}

The two Blumenavia species can be differentiate due to size and coloration of basidiomata. Blumenavia rhacodes has more robust, large basidiomata (up to $13 \mathrm{~cm}$ high), while $B$. angolensis is fragile and small (up to $6 \mathrm{~cm}$ ). Moreover, the first has yellowish, robust columns $(1-2 \mathrm{~cm}$ in diam.) and the latter has pure white (when fresh), narrower columns. In both species, the columns might be separated at the apex when the basidiome is old (also depicted by Degreef et al. 2013).

There are descriptions of $B$. rhacodes having orange columns, but probably they refer to misidentifications of Clathrus columnatus Bosc. According to our field experience, Blumenavia 
species are never orange. One collection of $B$. rhacodes from Trinidad was reported to have a white receptacle (Dennis 1953), so we cannot ascertain its identity, especially because measurements of receptacle and columns were not provided.
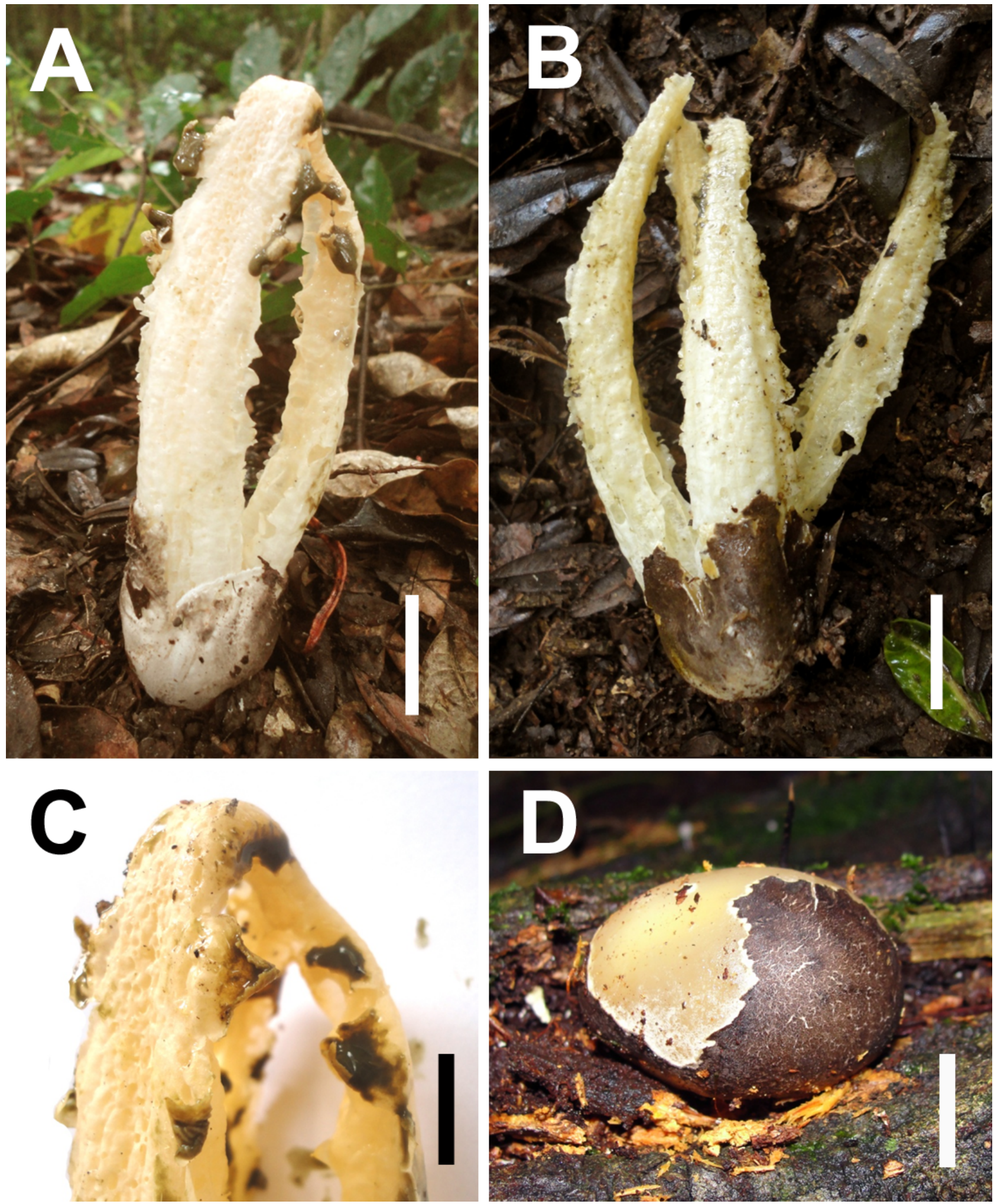

Figure 2 - Blumenavia rhacodes. A Basidiome in situ (ICN 177266). B Old basidiome with columns detached at the apex (ICN 177267). C Detail of the columns' apex (ICN 177266). D Immature basidiome about to expand (ICN 176968). - Bars A-B $=2 \mathrm{~cm} ; \mathrm{C}-\mathrm{D}=1 \mathrm{~cm}$. Photographs A-C by E.P. Fazolino. 
After our experience of observing several basidiomata in the field, we can ascertain that morphological features that are not constant and should not be taken into account to separate Blumenavia species are: color of immature basidiomata and/or volva, and distribution of the gleba.

In both species the immature stages might be whitish, grayish or blackish (note whitish volva in Fig. 2A and blackish volva in the Figs. 2B and 2D). More commonly the eggs are initially white, and then they become dark and cracked.

The gleba might be distributed all along the columns, but it might not be present when the basidiomata are found (maybe the receptacle is too young, or the gleba was wash out or removed by insects). We have seen typical specimens of $B$. rhacodes with gleba concentrated on the upper half of the columns, and we have seen basidiomata of $B$. angolensis were the lateral projections were evident but no mucilaginous gleba was visible in the 'teeth' (Fig. 1A). The original illustration of B. angolensis (Welwitsch \& Currey 1870) shows the gleba concentrated in the upper part of the columns, but we can ascertain that in this species this feature is not constant.
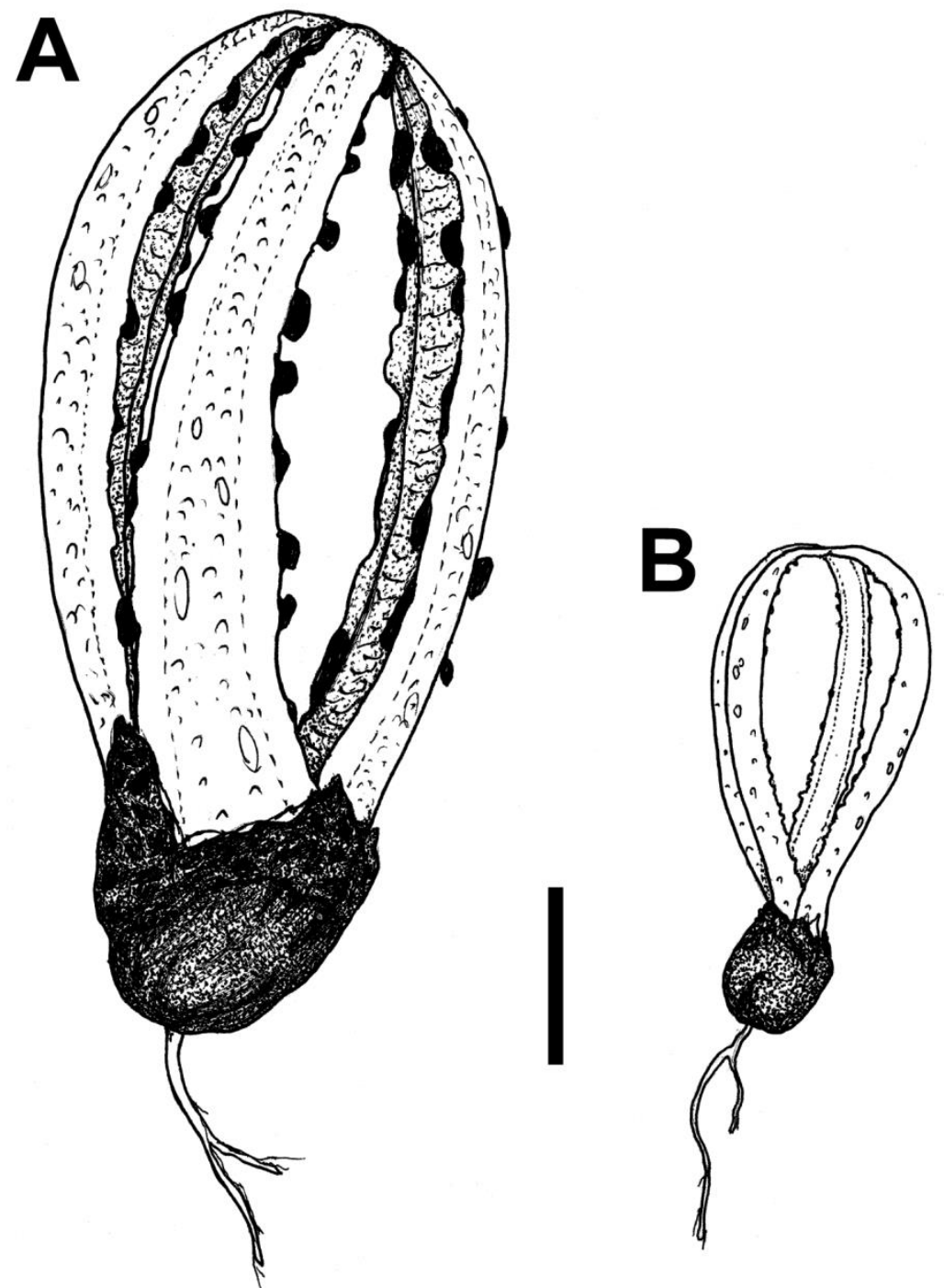

Figure 3 - Blumenavia species. A Blumenavia rhacodes B Blumenavia angolensis. - Bar $=2 \mathrm{~cm}$.

\section{Key to Blumenavia species}

1. Basidiomata robust, $9-13 \mathrm{~cm}$ high, columns up to $2 \mathrm{~cm}$ in wide when fresh, receptacle light yellow B. rhacodes

1'. Basidiomata delicate, $4-6 \mathrm{~cm}$ high, columns up to $0.5 \mathrm{~cm}$ in wide when fresh, receptacle pure white B. angolensis 


\section{Acknowledgements}

The authors are grateful to André A.R. de Meijer, Altielys C. Magnago and Eduardo P. Fazolino for supplying specimens, photographs, and/or information about the species. The co-first authors acknowledge CAPES (Brazilian Federal Agency for the Support and Evaluation of Graduate Education) for Ph.D. fellowships; L. Trierveiler-Pereira is thankful to PROPG-UFRGS for financing her visit to Herbarium BPI ('Edital 001/2013 - Missão Científica de Curta Duração no Exterior').

\section{References}

Calonge FD, Guzmán G, Ramírez-Guillén F, Gándara E. 2007 - Adiciones al catálogo de Gasteromycetes de México, con referencia especial a los géneros Blumenavia y Tulostoma. Boletín de la Sociedad Micológica de Madrid 31, 151-155.

Degreef J, Amalfi M, Decock C, Demoulin V. 2013 - Two rare Phallales recorded from São Tomé. Cryptogamie, Mycologie 34(1), 3-13.

Dennis RWG. 1953 - Some West Indian gasteromycetes. Kew Bulletin 8(3), 307-328.

Domínguez de Toledo LS. 1995 - Gasteromycetes (Eumycota) del centro y oeste de la Argentina. II. Orden Phallales. Darwiniana 33(1-4), 195-210.

Dring DM. 1980 - Contributions towards a rational arrangement of the Clathraceae. Kew Bulletin $35,1-96$.

Fischer E. 1933 - Gastromyceteae Stahelianae. Annales Mycologici 31(3), 113-125.

Kornerup A, Wanscher JH. 1978 - Methuen handbook of colour. 3rd Ed. Eyre Methuen, London.

López A, Martínez AL, García J. 1981 - Adiciones al conocimiento de los Phallales del estado de Veracruz. Boletín de la Sociedad Mexicana de Micología 16, 109-116.

Lloyd CG. 1909 - Synopsis of the known phalloids. Mycological Writings 3, 1-96.

Meijer AAR de. 2006 - Preliminary list of the macromycetes from the Brazilian State of Paraná. Boletim do Museu Botânico Municipal, Curitiba 68, Edição Especial, 1-55.

Miller Jr. OK, Miller HH. 1988 - Gasteromycetes: morphological and development features with keys to orders, families, and genera. Mad River Press, Eureka.

Möller A. 1895 - Brasilische Pilzblumen. Botanishe Mitteilungen aus den Tropen 7, 1-152.

Rick J. 1929. Phalloideas riograndenses. Egatea 14, 299-305.

Rick J. 1961 - Basidiomycetes Eubasidii in Rio Grande do Sul - Brasilia 6. Iheringia, Série Botânica 9, 451-479.

Rodrigues ACM, Baseia IG. 2013 - Blumenavia angolensis (Clathraceae), a rare phalloid reported from Northeastern Brazil. Mycosphere 4(6), 1066-1069.

Stafleu FA, Cowan RS. 1983 - Taxonomic literature. 2nd ed., Vol. IV. Bohn, Scheltema \& Holkema, Utrech.

Thiers B. 2011 [continuously updated] - Index Herbariorum: a global directory of public herbaria and associated staff. New York Botanical Garden's Virtual Herbarium. http:// sweetgum.nybg.org/ih/ (accessed 17 September 2013).

Trierveiler-Pereira L, Silveira RMB, Hosaka K. 2014 - Multigene phylogeny of the Phallales (Phallomycetidae, Agaricomycetes) focusing on some previously unrepresented genera. Mycologia (in press), doi: 10.3852/13-188

Vargas-Rodríguez YL, Vázquez-García JA. 2005 - Blumenavia toribiotalpaensis: a new species of Clathraceae from Jalisco, Mexico. Mycotaxon 94, 7-14.

Welwitsch F, Currey F. 1870 - Fungi Angolenses. A description of the fungi collected by Dr. Friedrisch Welwitsch in Angola during the years 1850-1861. Part I. Transactions of the Linnean Society of London 26, 279-294. 